\title{
MINERAL RESOURCE POTENTIAL OF THE SOUTHERN MASSANUTTEN ROADLESS AREA, PAGE AND ROCKINGHAM COUNTIES, VIRGINIA
}

\author{
By \\ Frank G. Lesure, U.S. Geological Survey \\ and \\ Mark L. Chatman, Paul T. Behum, and Thomas J. Wawro, U.S. Bureau of Mines
}

1983

Studies Related to Wilderness

Under the provisions of the Wilderness Act (Public Law 88-577, September 3, 1964) and related acts, the U.S. Geological Survey and U.S. Bureau of Mines have been conducting mineral surveys of wilderness and primitive areas. Areas officially designated as "wilderness," "wild," or "canoe" when the act was passed were incorporated into the National Wilderness Preservation System, and some of them are presently being studied. The act provided that areas under consideration for wilderness designation should be studied for suitability for incorporation into the Wilderness System. The mineral surveys constitute one aspect of the suitability studies. The act directs that the results of such surveys are to be made available to the public and be submitted to the President and the Congress. This report discusses the results of a mineral survey of the Southern Massanutten Roadless Area (08-175), Virginia. The area, which is in the George Washington National Forest in Page and Rockingham Counties, was classified for further planning during the Second Roadless Area Review and Evaluation (RARE II) of the U.S. Forest Service, January 1979.

\section{MINERAL RESOURCE POTENTIAL SUMMARY STATEMENT}

The Southern Massanutten Roadless Area is in the George Washington National Forest in the Valley and Ridge physiographic province of Page and Rockingham Counties, Va. The Federal Government owns all surface rights and the mineral rights on about 30 percent of the land. No mining, mineral leasing, or prospecting currently involves any of the roadless area, but a small amount of iron ore was mined in the area more than 70 years ago.

The area contains folded sedimentary rocks of Paleozoic age exposed in two long narrow synclines and an intervening anticline. These rocks have extensive resources of high-silica sandstone and inferred subeconomic iron resources of 120,000 long tons of clayey and sandy limonite containing 40 percent metallic iron. Other mineral resources include various shale deposits suitable for making brick, and limited amounts of limestone suitable for crushed stone and agricultural lime. Sandstone, shale, and limestone resources in the area are of limited value because of relative inaccessibility as compared with large, accessible resources of these materials outside the area.

The potential for commercial accumulations of oil or natural gas in the study area is unknown, but is probably low.

\section{INTRODUCTION}

The Southern Massanutten Roadless Area contains about 11,800 acres (4775 ha) in the George Washington National Forest in the Valley and Ridge physiographic province of west-central Virginia. The area, which is $13 \mathrm{mi}(21 \mathrm{~km})$ long and 1 to $2 \mathrm{mi}(1.5-3$ $\mathrm{km}$ ) wide, is in Page and Rockingham Counties on the eastern side of the Shenandoah Valley of Virginia between the North and South Forks of the Shenandoah River. The north end is $11 \mathrm{mi}(18 \mathrm{~km})$ southwest of Luray and the south end is $7 \mathrm{mi}(11 \mathrm{~km})$ east of Harrisonburg (fig. 1).

At the south end, the study area includes four parallel ridges named, from east to west, First, Second, Third, and Fourth IMountains (fig. 2).
Northeast of Runkles Gap, Cub Run Road forms the eastern boundary, and the northeast extension of First Mountain lies outside the study area. Second and Third Mountains merge at the Page-Rockingham County line; beyond this point to the northeast the study area includes just Third and Fourth Mountains. The higher altitudes range from $3,282 \mathrm{ft}(1000 \mathrm{~m})$ on Lairds Knob just south of the study area to $3,200 \mathrm{ft}(975 \mathrm{~m})$ on Grubbs Knob and 3,080 ft $(939 \mathrm{~m})$ on Morgan Knob in the study area; long stretches of the ridges are generally 2,600 to $2,800 \mathrm{ft}(790-850 \mathrm{~m})$ high. Low points are about $1,100 \mathrm{ft}(325 \mathrm{~m})$ along Cub Run near Catherine Furnace at the north end and about $1,600 \mathrm{ft}$ $(488 \mathrm{~m})$ on Boone Run at Runkles Gap near the south end. 


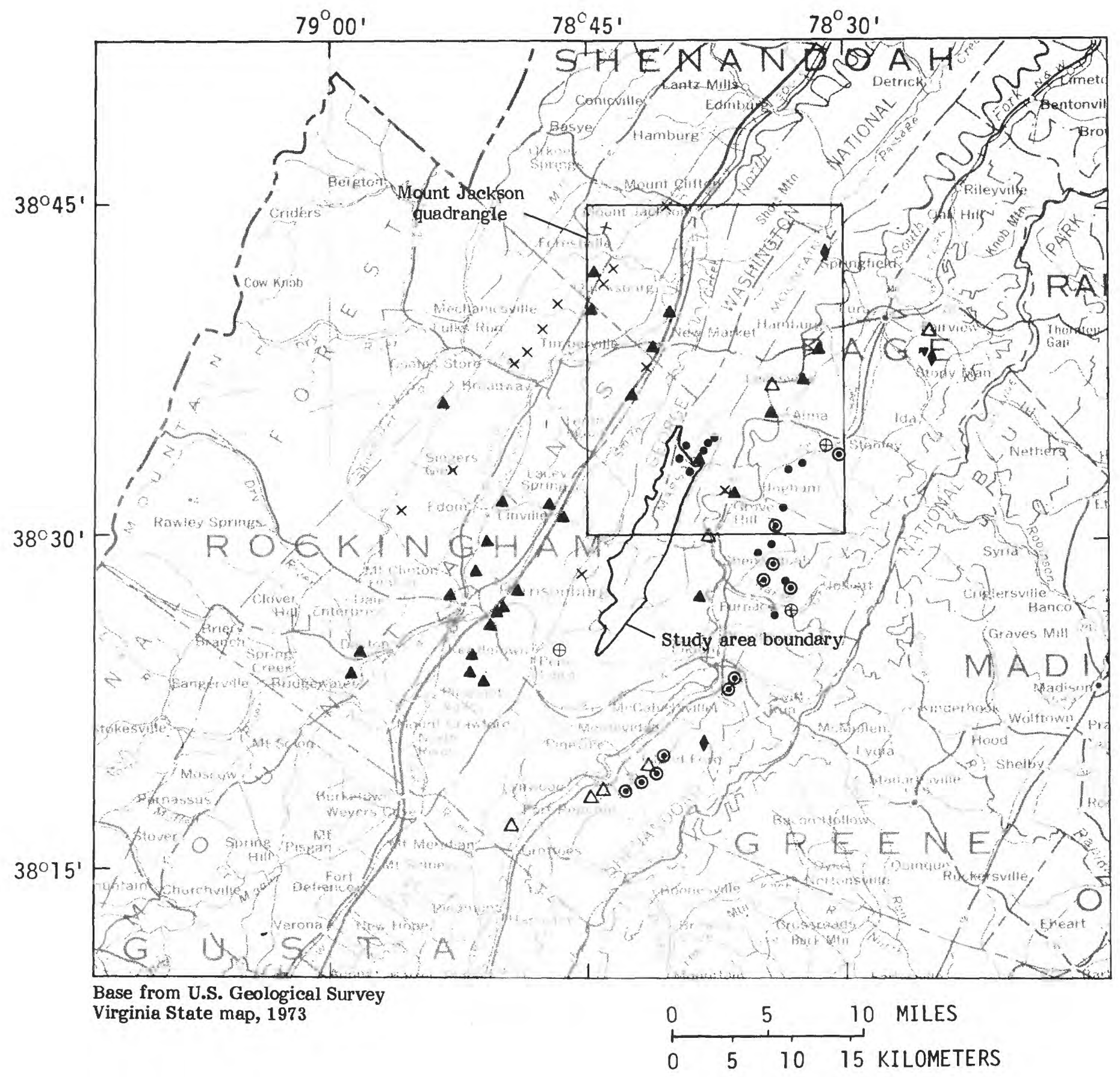

EXPLANATION

- Iron mine or prospect

A Limestone or dolomite quarry

- Manganese-iron mine or prospect

$\triangle$ Sand and gravel pit

$\times$ Zine mine or prospect

$\oplus$ Ocher mine or prospect

- Sandstone quarry

Figure 1.- Index map showing location of Southern Massanutten Roadless Area and some mines, prospects, and quarries in the region. (Mines, prospects, and quarries from Allen, 1967; Brent, 1960; and Herbert and Young, 1956.) 
The principal streams draining the east side of the area are Cub Run in the north half and Boone Run in the south half, both tributaries of the South Fork of the Shenandoah River. Mountain Run and its tributary Fridley Run drain an area between Third and Fourth Mountains along the west side of the study area.

The best access is from Cub Run Road along the east side, from the Pitt Spring Run Road along the north, and by a trail up to Fridley Gap on the west side. A trail from Pitt Spring at the north extends south along the east side of Fourth Mountain to Fridley Gap where it joins a trail that crosses Second and Third Mountains and intersects Cub Run Road near Peterfish Gap.

\section{Previous studies}

W. B. Rogers, the first State Geologist of Virginia, studied the geology in the general area of Massanutten Mountain as early as 1835 (1836, p. 90-91) and assigned numbers to the different rock units exposed there (Rogers, 1838 , p. 21-23). He recognized the synclinal structures of the mountains and correlated the rocks with his units numbered III through VIII (1839, p. 18). Lesley (1859, p. 69) mentioned the Catherine Furnace and the nearby iron deposits. Hotchkiss $(1878 ; 1880$, p. 56 , map, and p. 61) drew three cross sections across the study area and described briefly the iron ore in Massanutten Mountain. Darton (1892) applied the name Martinsburg Shale to Rogers' Unit III; Greiger and Keith (1891, p. 161) used the name Massanutten Sandstone for unit IV. Spencer (1897) made a reconnaissance study of the geology of Massanutten Mountain but dealt mostly with the northern half which is outside the study area. Holden (1907, p. 433) gave a brief mention of Catherine Furnace and the Pitt Spring iron mine. Charles Butts (1933) compiled a geologic map of the Appalachian Valley in Virginia which includes Massanutten Mountain and later described the lithologic units in detail (1940). Thornton (1953) mapped the geology of the Mt. Jackson 15-minute quadrangle which covers the northern half of the study area (fig. 1). Brent (1960) mapped and compiled the geology of Rockingham County which includes the southern half of the area; Allen (1967) mapped and compiled the geology for Page County which includes the northern half of the area (fig. 1). Roberts and Kite (1978) studied depositional features of the Massanutten Sandstone in the roadless area.

Calver and others (1961) reported clay analyses from Page and Rockingham Counties. Harris (1972) discussed the resource potential of the Massanutten Sandstone.

\section{Present studies}

From October 22 to 27, 1979, Lesure, assisted by J. H. DeYoung, Jr., and A. E. Grosz, U.S. Geological Survey (USGS), field checked previous geologic mapping and sampled the area. They collected 53 rock and 62 stream-sediment samples for trace-element analyses. All samples were analyzed in USGS laboratories, Denver, Colo. (Lesure and Forn, in press).

U.S. Bureau of Mines personnel T. J. Wawro, M. L. Chatman, and P. T. Behum conducted a field investigation of the roadless area in the spring and summer of 1980 . Forty-two samples of shale, sandstone, limestone, and iron-rich rocks, and three panned concentrates were collected for analysis (Wawro and others, 1982) by TSL Laboratories Ltd., Spokane, Wash. The U.S. Bureau of Mines, Tuscaloosa Research Center, Tuscaloosa, Ala., evaluated 11 shale samples for their ceramic properties and bloating characteristics.

\section{SURFACE- AND MINERAL-RIGHTS OWNERSHIP}

The U.S. Government owns all surface rights within the Southern Massanutten Roadless Area. Most of the acreage was acquired from the Alleghany Ore and Iron Co. between 1912 and 1915. Other tracts were bought from individual landowners. Surface restrictions include a right-of-way easement in the southern end of the area, and a power line across the northern end.

The Federal Government owns the mineral rights on 3,395 acres ( 1374 ha), about 30 percent of the total area. Alleghany Ore and Iron Co., now a subsidiary of Lukens Steel Co., Coatesville, Pa., holds the mineral rights on the remainder in perpetuity (fig. $3)$.

\section{GEOLOGY}

The Southern Massanutten Roadless Area consists of two narrow asymmetric synclines and an intervening anticline in Middle Ordovician to Middle Devonian sedimentary rocks (Lesure, in press). The oldest rocks are dark shaly limestone beds of the Edinburg Formation of Middle Ordovician age, poorly exposed on the lower western slopes of Fourth Mountain along the western boundary of the area. Overlying these beds are 1,000 to $4,000 \mathrm{ft}$ (300 to $1200 \mathrm{~m}$ ) of dark shale, siltstone, and limestone of the Martinsburg Shale of Middle and Late Ordovician age exposed on the east slope of First Mountain, in the valley between Second and Third Mountains, and on the western slope of Fourth Mountain. The Martinsburg is also exposed in the core of the anticline along Pitt Spring run at the north end of the study area.

Overlying the Martinsburg Shale is the Massanutten Sandstone of Early and Middle Silurian age. This unit is 500 to $800 \mathrm{ft}(150-240 \mathrm{~m})$ thick and is a white, fine- to coarse-grained crossbedded quartz sandstone that is resistant to erosion. The sandstone forms much of the bedrock in the study area. It crops out along the crests of all the ridges and supplies large quantities of coarse boulders which effectively conceal much of the less resistant formations on the lower slopes. Good exposures of the Massanutten are present along Cub Run just east of Catherine Furnace, along Pitt Spring Run east of Pitt Spring, along the road in Runkles Gap, and along the trail in Fridley Gap.

The Silurian and Devonian formations above the Massanutten Sandstone are poorly exposed along the axes of the synclines between First and Second and between Third and Fourth Mountains. These rocks include in ascending order about 200 to $340 \mathrm{ft}(60-100$ $\mathrm{m})$ of red shale, siltstone, and sandstone of the Bloomsburg Formation and 35 to $50 \mathrm{ft}(10-15 \mathrm{~m})$ of thin-bedded limestone of the Tonoloway Limestone, both of Late Silurian age. Above this sequence is $80 \mathrm{ft}$ $(24 \mathrm{~m})$ of light-gray, coarse-grained limestoneCatherine Limestone of Thornton (1953)-of Late Silurian to Early Devonian age. The youngest formation in the study area is the Romney Shale of 


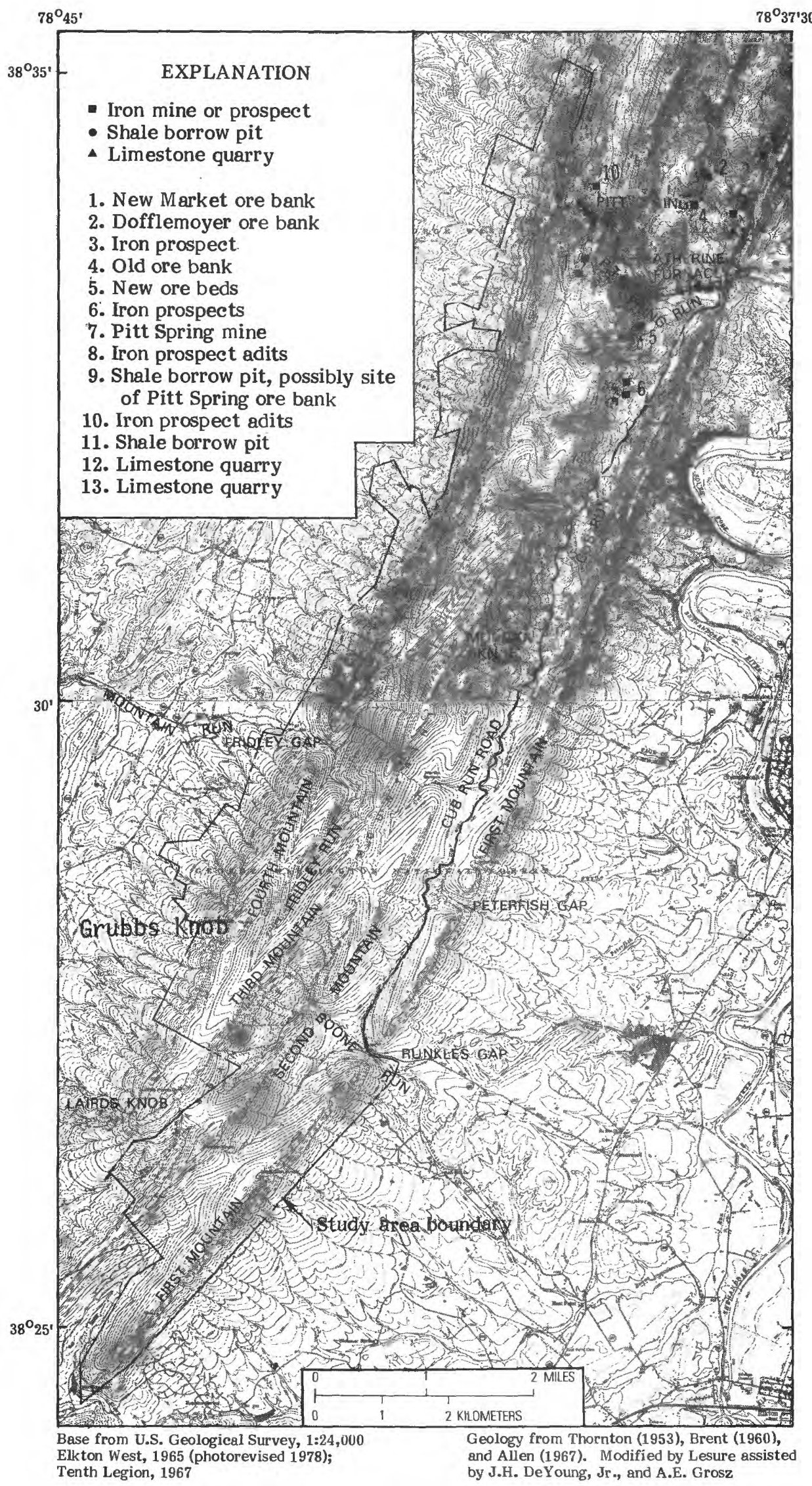

Figure 2.--Topographic features of Massanutten Mountain and location of mines and prospects in and near the roadless area. 


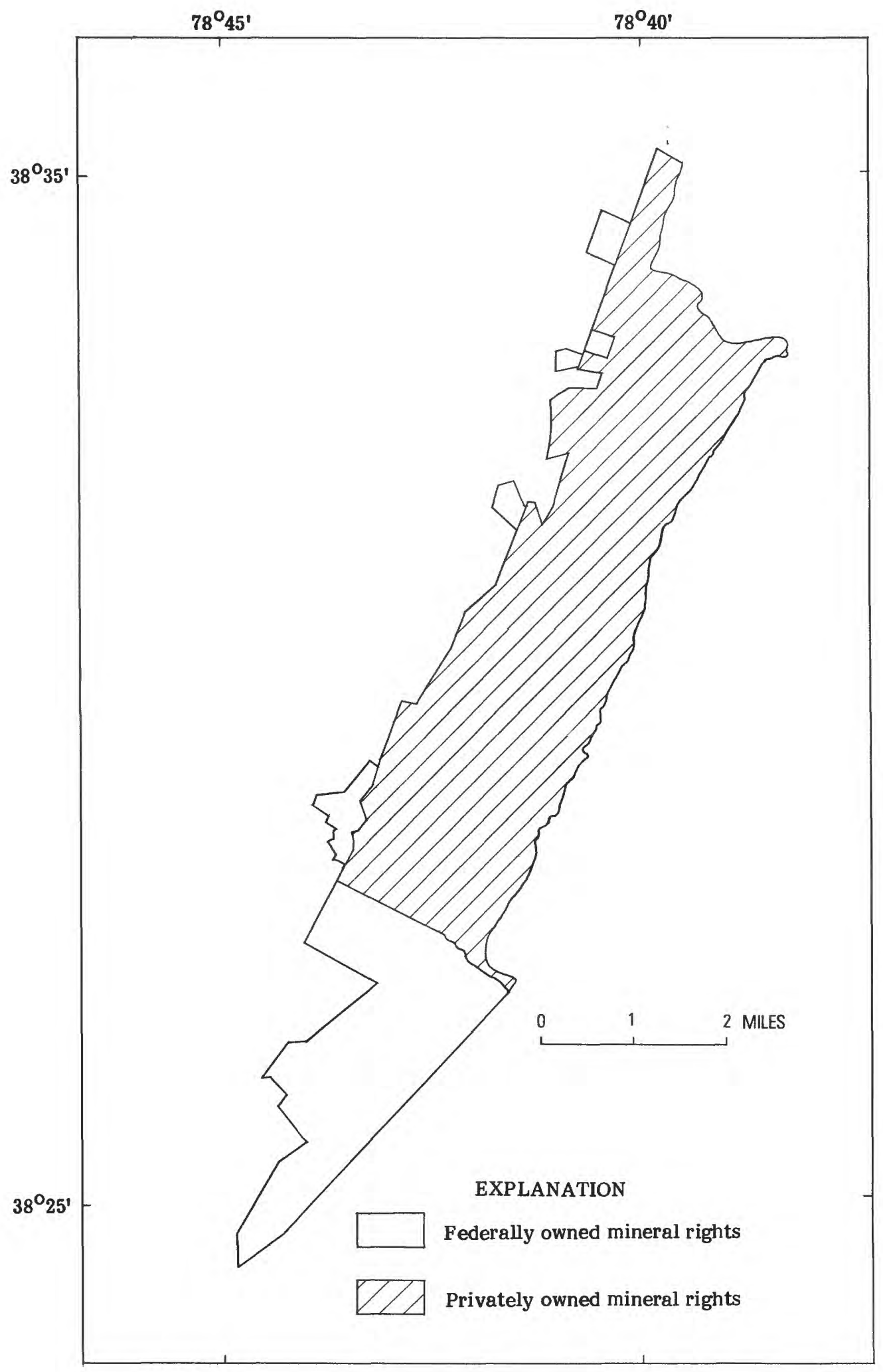

Figure 3.-Map showing mineral-rights ownership, Southern Massanutten Roadless Area. 
Middle Devonian age, which includes $100 \mathrm{ft}(30 \mathrm{~m})$ of grayish-green shale at the base, correlated with the Needmore Shale, and an unknown thickness of black fissile shale above, correlated with the Millboro Shale.

The hillsides and narrow valleys of the study area are generally covered by coarse boulders of Massanutten Sandstone and minor amounts of the red sandstones of the Bloomsburg Formation.

Although no major faults are exposed in the study area, a zone of major flat-lying thrust faults is present at a depth of 2 to $5 \mathrm{mi}(3-8 \mathrm{~km})$ below the study area (Milici, 1980, sheet 1 ). The rocks exposed in the study area have been moved westward many miles along these faults.

\section{GEOCHEMICAL SURVEY}

Reconnaissance geochemical sampling in the Southern Massanutten Roadless Area was designed to test for indistinct or unexposed mineral deposits that might be recognized by their geochemical halos (Lesure and Forn, in press). Similar geochemical surveys based on trace-element analyses have been credited with the discovery of many types of mineral deposits (Hawkes and Webb, 1962). The only metallic mineral deposits known in the area are the low-grade iron deposits at the Pitt Spring mine and New Ore beds prospects (fig. 2); no evidence of other metallic deposits was found. Traces of zinc (0.2-0.3 percent) in the limonitic sandstone from the Pitt Spring mine (Lesure and Forn, in press), are similar to amounts found in other iron deposits of this type (Lesure and others, 1978; Lesure, 1982) and are not considered to be of economic importance.

\section{MINING ACTIVITY}

Since the early 1800 's, iron, manganese, lead, zinc, limestone, shale, sandstone, and sand and gravel have been mined, quarried, or prospected in or near the Southern Massanutten Roadless Area (fig. 1). The only mining activity within the study area took place during the late $1800^{\prime}$ 's and early 1900's when limonitic iron ore was mined at the Pitt Spring mine and the New Ore beds prospects (fig. 2). Additional iron mining occurred north of the study area in several mines in Roaring Run Valley (fig. 2). Small amounts of limestone and shale have been quarried at the margin of the area (fig. 2).

Catherine Furnace, built of Massanutten Sandstone in 1846, used iron ore from limonite deposits $0.75 \mathrm{mi}(1.2 \mathrm{~km})$ "west of north from the furnace" (Lesley, 1859, p. 68), probably those of the Old Ore Bank, or Dofflemoyer mines just north of the study area (fig. 2). The furnace made "526 tons of metal out of brown hematite ore" during a 22-week period in 1856 (Lesley, 1859 , p. 68), but according to King (1950, p. 68) has not been in operation since 1860 .

Workings at the Pitt Spring mine consist of two large open cuts, $200 \mathrm{ft}$ and $300 \mathrm{ft}$ long, several caved adits, and numerous prospect pits distributed over a distance of 4,800 ft along the northwest slope of Third Mountain (Chatman and Behum, in press).

A series of prospect pits on the east slope of Third Mountain extends for at least a mile $(1.6 \mathrm{~km})$ southwest of Pitt Spring Run to beyond Lokey Hollow. This linear prospect area was shown as the

$1_{\text {Inferred resources are estimated extensions of a }}$ mineral deposit into areas for which there is geologic evidence of its continuity, beyond the points at which the resources were "demonstrated" or directly
New Ore Beds on a map by Hotchkiss (1878). The pits are caved and overgrown; some have limonite fragments on the dump, but many do not. They range in size from 6 to $30 \mathrm{ft}(2-10 \mathrm{~m})$ in diameter and from 3 to $15 \mathrm{ft}(1-5 \mathrm{~m})$ in depth. The larger pits, about halfway between Pitt Spring Run and Lokey Hollow, may have supplied minor amounts of limonite, but the shallowness and general small size of most other pits and the lack of limonite on the dumps suggest that the mineralized zone was thin and low grade.

Two small abandoned shale pits are along Pitt Spring Run (fig. 2, sites 9 and 11). The shale was probably used in construction of local roads.

Two small quarries (fig. 2, sites 12 and 13) apparently produced limestone from the Upper Silurian and Lower Devonian limestone for flux in Catherine Furnace (Hotchkiss, 1878, p. 37).

\section{MINERAL RESOURCES}

Identified mineral resources of sandstone suitable for common building stone, crushed rock, and high-silica sand, and shale suitable for common brick, tile, and lightweight aggregate, are in the study area (fig. 4), but are subeconomic at this time. The limonitic-iron deposits, worked more than 70 years ago, have inferred subeconomic resources ${ }^{1}$ of 120,000 long tons of limonitic material containing as much as 40 percent metallic iron. The area has essentially no potential for accumulation of either oil or natural gas because the rocks have been heated to temperatures at which oil and gas are unstable (Epstein and others, 1977; Harris and others, 1978), and the structural setting of the Massanutten Synclinorium is unfavorable for oil and gas accumulation. Potential for oil or natural gas in sedimentary rocks below the Pulaski thrust fault, which underlies the area at a depth of 2 to $5 \mathrm{mi}(3-8 \mathrm{~km})$, is unknown. There are no identified resources of other commodities in the area; the probablity for the occurrence of undiscovered resources of other mineral commodities is small.

\section{Sandstone}

The Massanutten Sandstone, present in large amounts in the study area, represents a subeconomic resource. It is a potential source of large amounts of stone suitable for common building stone, crushed rock, and high-silica sand. A quarry on Massanutten Mountain, $12.5 \mathrm{mi}(20 \mathrm{~km})$ northeast of Catherine Furnace, supplied building, wall, and coping stone as late as the 1960's (Allen, 1967, p. 64; Harris, 1972, p. 4).

Analyses of representative samples (Wawro and others, 1982, p. 18; Lesure and Forn, in press) suggest that the Massanutten Sandstone is suitable for low quality glass products without beneficiation. Because the Massanutten consists of nearly pure silica sand, it could possibly be used for refractory sand, abrasive material, or silica for chemical and metallurgical uses (Murphy, 1960; Ries, 1949). Complete evaluation for the special silica uses requires additional testing of physical characteristics. Because adequate silica resources are present outside the study area in this formation and in others which are closer to main highways and transportation, the sandstone in the study area is subeconomic.

observed. Subeconomic resources are those which cannot be extracted with any certainty of a profit (U.S. Bureau of Mines and U.S. Geological Survey, 1980). 
Several samples of Martinsburg Shale from the flanks of Massanutten Mountain have been tested and found suitable for common brick, tile, and lightweight aggregate (Calver and others, 1961, p. 102-105, 128144; Wawro and others, 1982, p. 15). The most accessible part of shale resources in the Martinsburg Shale are along the flanks of the mountain, generally outside the study area.

Silurian and Devonian shales in the synclinal valleys of the study area were subjected to preliminary ceramic testing, which shows a potential use for structural clay products (Wawro and others, 1982, p. 15). One sample of shale from the Upper Silurian Bloomsburg Formation also was found to be suitable for lightweight aggregate (Wawro and others, 1982, p. 15 ), but this rock unit is predominantly a sandstone in the study area and does not contain significant shale beds.

Preliminary testing results do not represent a complete resource analysis, and extensive sampling and testing are necessary before commercial development consideration. Shale is usually a lowunit-value material, and its development depends on market proximity. No attempt has been made to develop shale deposits in or near the study area, and the probability for such development is presently low.

\section{Iron}

Deposits of medium-grade clayey and sandy limonitic iron are common in this part of west-central Virginia where they have been called Oriskany iron ores (Holden, 1907, p. 408-410). These ores formed during a long period of weathering during which groundwater dissolved iron from pyrite in the Romney Shale and precipitated iron hydroxides as supergene replacement and cavity filling in the underlying Lower Devonian limestone. In general, these deposits are near-surface features; the iron ore grades into unreplaced limestone within a hundred feet $(30 \mathrm{~m})$ or less of the surface. In the Clifton Forge iron district $70 \mathrm{mi}(110 \mathrm{~km})$ southwest of Massanutten Mountain the larger iron deposits occur where the limestone beds dip 20 to 75 degrees (Lesure, 1957, p. 94). Only a few deposits occur in steeply dipping or overturned beds such as those predominating in the study area.

In the study area, structure is apparently a major factor limiting iron replacement of the coarsegrained Upper Silurian and Lower Devonian limestones above the Tonoloway Limestone. Iron deposits are found in discontinuous zones parallel to the axes of the synclinal valleys along Pitt Spring Run, Cub Run, and Roaring Run where the formations dip less than 75 degrees. The iron deposits are on both limbs of the syncline along Roaring Run valley, but only on the west limb to the south in Cub Run Valley. At the Pitt Spring mine, the ore is apparently developed only on the eastern limb of the syncline, where the rocks dip about 45 degrees to the northwest. On the western limb of the syncline the beds are overturned, with the result that the coarse-grained limestones are topographically above the iron-rich shale source-beds, restricting the possibilities for mineralization. Limonite fracture fillings, however, do occur in calcareous gray shale along Pitt Spring Run. Other iron deposits may be concealed by the thick cover of Massanutten Sandstone colluvium. Exposures of

${ }^{2}$ One long ton (2240 lbs) is nearly equal to one metric ton (2204.6 lbs). massive but porous limonite $3-10 \mathrm{ft}$ thick are in the two large open cuts at the Pitt Spring mine, but most of the material consists of limonite stringers, veins, and pods in a matrix of soft, ferruginous clay and shale. The massive limonite has a brecciated porous texture and contains numerous vugs coated or partly filled with manganese oxides, white clay, or, rarely, specular hematite. The Pitt Spring ore zone probably does not extend much beyond the southern pits of the Pitt Spring mine. The limestone and shale formations along this eastern limb of the syncline have been removed by erosion not far south of the Pitt Spring mine, and beyond this area only the Bloomsburg Formation and Tonoloway Limestone are present.

Parallel iron-bearing zones have been mined or prospected in Roaring Run Valley, immediately north of the study area (fig. 2) and to the south in the study area along the western limb of the syncline along Cub Run Valley at least as far as the area between Lokey and Koontz Hollows. This western limb of the easternmost syncline is steeply dipping to overturned south of Koontz Hollow, and was probably not favorable for significant iron deposition to the south.

\section{Iron resources}

Iron resources in Oriskany-type deposits are difficult to estimate without extensive trenching and drilling, which was not done during this study. In the area of the Pitt Spring mine, the surface is generally covered with boulder debris from the Massanutten Sandstone and the old mine workings are caved and overgrown. The lack of outcrops and subsurface data precludes precise estimates of iron resources. The iron resources are probably restricted to the area of past mining or prospecting. The lack of significant amounts of limonite on the dumps of the small pits between the two large cuts and on strike beyond the cuts also suggests that ore-grade material was found only in the area of the large cuts. The shape of the cuts indicates that the ore was in tabular masses 5-15 ft (1.6-5 m) thick. A tabular body $15 \mathrm{ft}(5 \mathrm{~m})$ thick was mined in the southern cut, whereas one $5-10 \mathrm{ft}$ $(1.6-3 \mathrm{~m})$ thick was mined in the northern cut. An ore grade of 40 percent iron, as given by Holden (1907, p. 433), probably represents the average grade of material mined. A tonnage factor of $13 \mathrm{cu} f \mathrm{ft}$ per long ton $^{2}$ for rock in place (Morrison and Grosh, 1950, p. 13 ) is a reasonable estimate for this type of iron ore. The total length of open cut is about $500 \mathrm{ft}(150 \mathrm{~m})$ and the distance between the cuts is $500 \mathrm{ft}(150 \mathrm{~m})$. An additional $800 \mathrm{ft}(240 \mathrm{~m})$ along strike to the southwest and northeast has been prospected, but only the pits for about $300 \mathrm{ft}(100 \mathrm{~m})$ northeast of the northern cut have much limonite on the dumps.

Assuming $200 \mathrm{ft}(60 \mathrm{~m})$ of strike length, $15 \mathrm{ft}$ ( 5 $\mathrm{m})$ of thickness, and $100 \mathrm{ft}(30 \mathrm{~m})$ of downdip extension for the southern ore body, and $300 \mathrm{ft}(100 \mathrm{~m})$ of strike length, $10 \mathrm{ft}(3 \mathrm{~m})$ of thickness, and $100 \mathrm{ft}(30 \mathrm{~m})$ of downdip extension for the northern ore body, we can calculate $600,000 \mathrm{cu} \mathrm{ft}\left(17,000 \mathrm{~m}^{3}\right)$ of ore-zone material. An additional $400,000 \mathrm{cu} \mathrm{ft}\left(11,000 \mathrm{~m}^{3}\right)$ of mineralized rock may be assumed in the area between the cuts and for $300 \mathrm{ft}(100 \mathrm{~m})$ northeast of the northern cut. Dividing by the tonnage factor $(13 \mathrm{cu} \mathrm{ft}$ per long ton) yields inferred subeconomic resources of 80,000 long tons of limonite-bearing material. At an average content of 40 percent iron, this would yield about 30,000 long tons of iron at the Pitt Spring mine. 


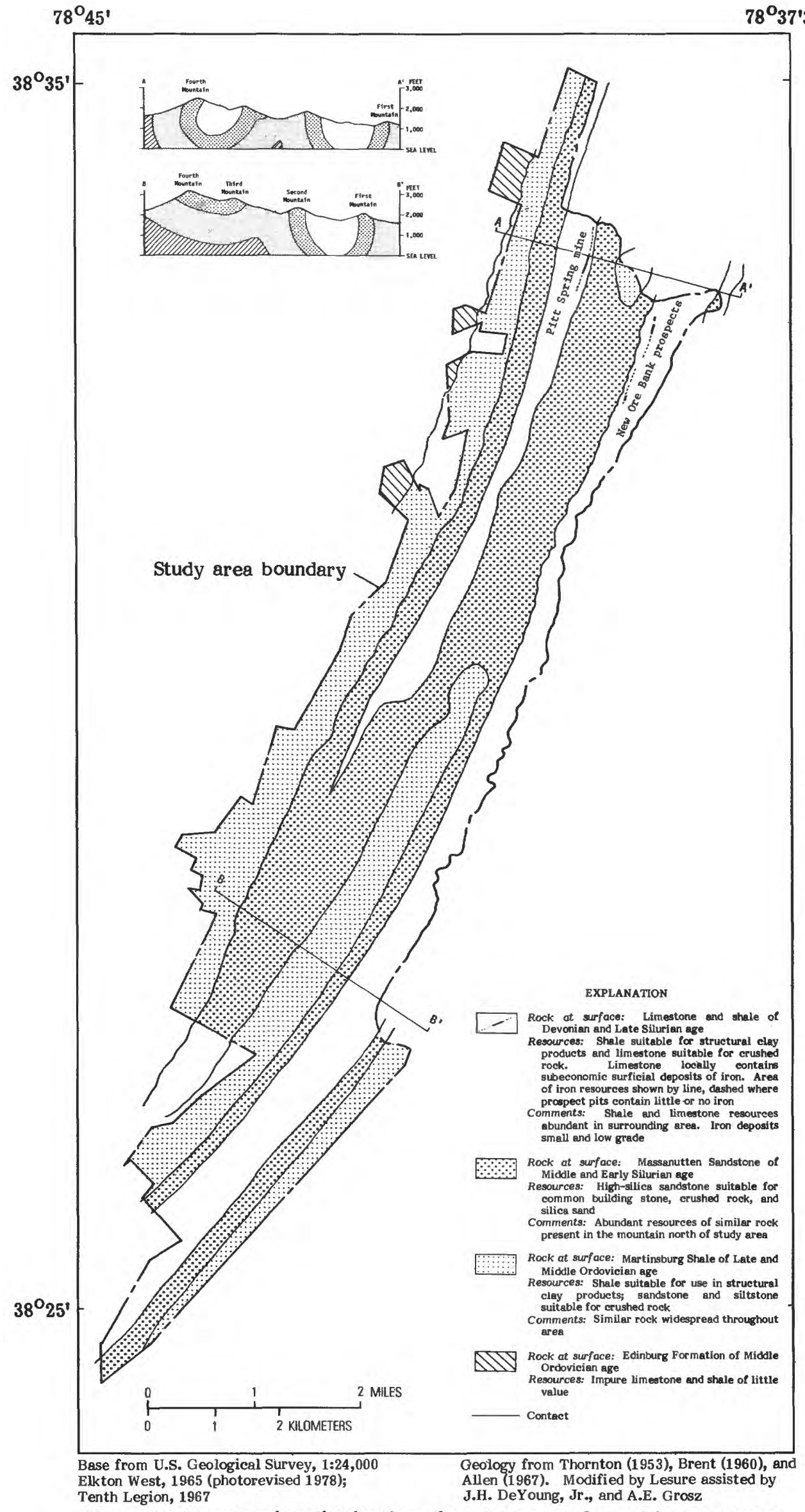

Figure 4.-Map showing distribution of sandstone, shale, and iron resources in the Southern Massanutten Roadless Area. 
The prospecting on the east slope of Third Mountain extends for a mile southwest of Pitt Spring Run, but only a few pits covering $1000 \mathrm{ft}(300 \mathrm{~m})$ or so of this distance have significant amounts of limonite on the dumps. Inferred resources in this area calculated for $1000 \mathrm{ft}(300 \mathrm{~m})$ of strike length, an average thickness of $5 \mathrm{ft}(1.6 \mathrm{~m})$, and a possible $100-\mathrm{ft}$ $(30-\mathrm{m})$ extension downdip amount to $500,000 \mathrm{cu} \mathrm{ft}$ $\left(14,000 \mathrm{~m}^{3}\right)$ of rock or approximately 40,000 long tons of subeconomic iron resources containing 16,000 long tons of iron. The small size and shallow depth of the pits in this area and the lack of much limonite on the dumps of many of the pits suggest, however, that no mass of mineralized rock large enough to justify mining was discovered. Hotchkiss shows this area of prospecting on his map (Hotchkiss, 1878) but not that of the Pitt Spring mine, and we assume these eastern pits were dug first.

There is currently no market for Virginia's Oriskany-type iron resources, which occur in relatively small, discontinuous deposits of nonuniform grade. Modern blast furnaces require large tonnages of uniform-grade iron ores. Average phosphorous content of the Pitt Spring deposit is about 0.6 percent. Values exceeding 0.1 percent phosphorous are considered high for modern steel manufacturing. Consequently, the iron resources of Southern Massanutten Roadless Area are unlikely to be utilized in the foreseeable future.

\section{Oil and gas resources}

The probability that undiscovered resources of oil and natural gas occur in the Southern Massanutten Roadless Area is low. Based on the data available it would appear that no commercial quantities of gas or oil occur in the area because the rocks have been heated to temperatures at which oil and gas break down (called high thermal maturation) and the structural setting is unfavorable for the accumulation of oil or gas (Wallace de Witt, Jr., USGS, 1981, written commun.).

Oil and gas accumulation is dependent on the presence of source beds and their level of thermal maturation, on the presence of reservoir rocks, on the regional and local structure including the presence of traps capable of retaining oil or gas, and on the existence of seals to prevent the escape of hydrocarbons from reservoir strata. Areas in which many wells have been drilled and for which lithologic and wire-line geophysical logs, drill cuttings, core analyses, and well production history are available permit evaluation of oil and gas resources, whereas only subjective speculative analyses are possible in areas where little or no drilling has been done, seismic profiling and other geophysical data are unavailable, and the subsurface geology is at best only poorly known from the extrapolation of surface data. The Southern Massanutten Roadless Area falls into the poorly-known category. Subsurface data are largely nonexistent; deep wells have not been drilled in the area. No acreage in the study area is leased for oil and gas.

Although the study area contains source beds for oil and gas, these occur only in the near-surface rocks. Reservoir rocks with original intergranular porosity and permeability are rare and appear to be present only in the near-surface beds that generally crop out on Massanutten Mountain. The general synclinal structure of the mountain favors migration of light fluid hydrocarbons to outcropping reservoir rocks rather than forming traps capable of retaining oil or gas. Zones of open fracture porosity may exist at depth associated with buried thrust faults and splay faults (Milici, 1980). High levels of thermal maturation of both source beds and reservoir rocks at the surface and probably at depth below the Pulaski thrust fault (Harris and others, 1978) preclude the existence of oil or commercial quantities of natural gas in the Southern Massanutten Roadless Area. The thermal maturity of the lowermost sedimentary rocks below the zone of thrust faulting (Harris, 1979, p. 529) is unknown, but this unit of rocks is probably thin and is an unlikely source of oil or gas (Wallace de Witt, Jr., USGS, 1981, oral commun.).

\section{Other mineral commodities}

The limestone sequence of Late Silurian and Early Devonian age is a potential source of crushed rock for a variety of purposes. The valley area surrounding Massanutten Mountain, however, is a major source of aggregate from much more extensive deposits of limestone and dolomite in Upper Cambrian to Middle Ordovician carbonate rocks. Consequently the limestone in the study area is a subeconomic resource.

Zinc sulfides sporadically occur as disseminations or fracture fillings in Cambrian and Ordovician carbonates throughout the Shenandoah Valley (Herbert and Young, 1956). Some lead occurrences are also known. Several zinc prospects are located near the study area (fig. 1). Similar deposits may occur in the study area in these same formations at depths probably greater than 4,000 $\mathrm{ft}$ $(1,200 \mathrm{~m})$, but because of their small size and great depth such deposits most likely would be subeconomic. Manganese was mined with iron at localities in the Shenandoah Valley near the study area. Iron-rich materials sampled in the study area contain low concentrations of manganese, and no deposits of predominant manganese mineralization were observed.

\section{REFERENCES CITED}

Allen, R. M., Jr., 1967, Geology and mineral resources of Page County: Virginia Division of Mineral Resources Bulletin 81, 78 p.

Brent, W. B., 1960, Geology and mineral resources of Rockingham County: Virginia Division of Mineral Resources Bulletin 76, 174 p.

Butts, Charles, 1933, Geologic map of the Appalachian Valley of Virginia, with explanatory text: Virginia Geological Survey Bulletin 42, 56 p. 1940, Geology of the Appalachian Valley in Virginia: Virginia Geological Survey Bulletin no. $52,568 \mathrm{p}$.

Calver, J. L., Hamlin, H. P., and Wood, R. S., 1961, Analyses of clay, shale, and related materialsnorthern counties: Virginia Division of Mineral Resources, Mineral Resources Report 2, 194 p.

Chatman, M. L. and Behum, P. T., in press, Map showing mines and prospects in the Southern Massanutten Roadless Area, Page and Rockingham Counties, Virginia: U.S. Geological Survey Miscellaneous Field Studies Map MF-1527-C.

Darton, N. H., 1892, Notes on the stratigraphy of a portion of central Appalachian Virginia: American Geologist, v. 10, p. 10-18. 
Eckel, E. C., 1906, The Oriskany and Clinton iron ores of Virginia, in Contributions to economic geology, 1905: U.S. Geological Survey Bulletin 285, p. $183-189$.

Epstein, A. G., Epstein, J. B., and Harris, L. D., 1977, Conodont color alteration index to organic metamorphism: U.S. Geological Survey Professional Paper 995, 27 p.

Greiger, H. R., and Keith, Arthur, 1891, The structure of the Blue Ridge near Harper's Ferry: Geological Society of America Bulletin, no. 2, p. 155-164.

Harder, E. C., 1909, The iron ores of the Appalachian region in Virginia, in Contributions to economic geology, 1908; Part I-Metals and nonmetals, except fuels: U.S. Geological Survey Bulletin 380 , p. 215-254.

Harris, A. G., Harris, L. D., and Epstein, J. B., 1978, Oil and gas data from Paleozoic rocks in the Appalachian basin: Maps for assessing hydrocarbon potential and thermal maturity (Conodont color isograds and overburden isopachs): U.S. Geological Survey Miscellaneous Investigations Series Map I-917-E.

Harris, L. D., 1979, Similarities between the thickskinned Blue Ridge anticlinorium and the thinskinned Powell Valley anticline: Geological Society of America Bulletin, Part I, v. 90, p. 525539.

Harris, W. B., 1972, High-silica resources of Clarke, Frederick, Page, Rockingham, Shenandoah, and Warren Counties, Virginia: Virginia Division of Mineral Resources, Mineral Resources Bulletin $11,42 \mathrm{p}$.

Hawkes, H. E., and Webb, J. S., 1962, Geochemistry in mineral exploration; New York, Harper and Row, 415 p.

Herbert, Paul, Jr., and Young, R. S., 1956, Sulfide mineralization in the Shenandoah Valley of Virginia: Virginia Divison of Geology Bulletin 70, $58 \mathrm{p}$.

Holden, R. J., 1907, Iron in Watson, T. L., Mineral resources of Virginia: Lynchburg, Va., Virginia Jamestown Exposition Commission, p. 402-491.

Hotchkiss, Jedediah, 1878, The Shenandoah Iron, Lumber, Mining, and Manufacturing Company of Virginia; A report on its charter, lands, iron ores, and other minerals, timber, water-powers, ironworks, and other improvements and commercial facilities: Staunton, Va., D. E. Strasburg, 71 p. 1880, The Shenandoah Valley Railroad and the mineral and other resources of the country tributary to it: The Virginias, v. 1, p.36-37, 40, 56-57, 60-61.

King, P. B., 1950, Geology of the Elkton area, Virginia: U.S. Geological Survey Professional Paper 230, $82 \mathrm{p}$.

Lesley, J. P., 1859, The iron manufacturer's guide to the furnaces, forges, and rolling mills of the United States: New York, John Wiley, 772 p.

Lesure, F. G., 1957, Geology of the Clifton Forge iron district, Virginia: Virginia Polytechnic Institute Bulletin, Engineering Experiment Station Series, no. 118,130 p. 1982, Geochemical survey of the Dolly Ann Roadless Area, Alleghany County, Virginia: U.S. Geological Survey Miscellaneous Field Studies Map MF-1358-B, scale 1:48,000. in press, Geologic map of the Southern Massanutten Roadless Area, Page and Rockingham Counties, Virginia: U.S. Geological Survey Miscellaneous Field Studies Map MF-1527-A, scale 1:48,000.

Lesure F. G., and Forn, C. L., in press, Geochemical maps of the Southern Massanutten Roadless Area, Page and Rockingham Counties, Virginia: U.S. Geological Survey Miscellaneous Field Studies Map MF-1527-B.

Lesure, F. G., Williams, B. B., and Dunn, M. L., Jr., 1978, Mineral resources of the Mill Creek, Mountain Lake, and Peters Mountain Wilderness Study Areas, Craig and Giles Counties, Virginia, and Monroe County, West Virginia: U.S. Geological Survey Open-File Report OF-78-1076, 69 p.

Milici, R. C., 1980, Relationship of regional structure to oil and gas producing areas in the Appalachian basin: U.S. Geological Survey Miscellaneous Investigations Series Map I-917-F.

Morrison, G. A., and Grosh, W. A., 1950, Investigation of Oriskany iron-ore deposits, Alleghany, Bath, Botetourt, and Craig Counties, Virginia.: U.S. Bureau of Mines Report of Investigations 4668, $59 \mathrm{p}$.

Murphy, T. D., 1960, Silica sand and pebble, in Industrial minerals and rocks, 3rd ed.: American Institute of Mining, Metallurgical, and Petroleum Engineers, p. 763-772.

Ries, Hienrich, 1949, Special sands, in Industrial minerals and rocks, 2 nd ed.: American Institute of Mining and Metallurgical Engineers, New York, p. 973.

Roberts, W. P., and Kite, J. S., 1978, Syntectonic deposition of Lower to Middle Silurian sandstones, central Shenandoah Valley, Virginia: Virginia Minerals, v. 24, no. 1, p. 1-5.

Rogers, W. B., 1836, Report of the geological reconnaissance of the State of Virginia: Philadelphia, Pa., Desilver, Thomas and Co., 144 p. 1838, Report of the progress of the geological survey of the State of Virginia for the year 1837 (Document No. 45): [Richmond, Va.] , 24 p. 1839, Report of the progress of the geological survey of the State of Virginia for the year 1838 (Document No. 56): [Richmond, Va. ], 24 p.

Spencer, A. C., 1897, The geology of Massanutten Mountain in Virginia: Privately published Ph.D. thesis, Johns Hopkins University.

Thornton, C. P., 1953, The geology of the Mount Jackson quadrangle, Virginia: Unpublished Ph.D. dissertation, Yale University, $211 \mathrm{p}$.

U. S. Bureau of Mines and U.S. Geological Survey, 1980, Principles of a resource/reserve classification for minerals: U.S. Geological Survey Circular 831, 5 p.

Wawro, T. J., Chatman, M. L., and Behum, P. T., 1982, Mineral investigation of the Southern Massanutten RARE II Further Planning Area, Page and Rockingham Counties, Virginia: U.S. Bureau of Mines Open-File Report MLA 73-82, 1982, 26 p. 